\title{
The Anti-tubercular Activity of Noni Fruitsto Inhibition Growth of Multi Drug Resistant-Tuberculosis Bacteria
}

\section{Novie Elvinawaty Mauliku}

Public Health Study Program, Sekolah Tinggi Ilmu Kesehatan Jenderal Achmad Yani, Cimahi, Indonesia

\section{ORCID:}

Novie Elvinawaty Mauliku: https://orcid.org/0000-0002-5953-9348

\section{Abstract}

Multidrug-resistant tuberculosis (MDR-TB) is a tuberculosis infection that is resistant to the treatment at least two of the most powerful anti-tuberculosis drugs, such as Isoniazid and Rifampisin. Increased cases of MDR-TB in morbidity and mortality become obstacles in the control of tuberculosis (TB), thus requiring supportive treatment of natural ingredients that can contribute in the treatment of TB, such a noni fruit. The

Corresponding Author: Novie Elvinawaty Mauliku noviemauliku.unjani@gmail.com

Published: 15 March 2021

Publishing services provided by Knowledge E

(c) Novie Elvinawaty

Mauliku. This article is distributed under the terms of the Creative Commons

Attribution License, which permits unrestricted use and redistribution provided that the original author and source are credited.

Selection and Peer-review under the responsibility of the IVCN Conference Committee.
G OPEN ACCESS main objective of this study was extract of noni fruits to inhibition the growth of strain MDR-TB bacteria, and compered it with the anti-TB drugs. The Morinda $c$. Linn (Noni) fruits was extraced by ethanol (96\%). The extract was filtered through whatman No.1 filter paper, evaporated to dryness on a water bath until the solvent evaporated completely and yield of the crude extract. The experiment were divided into 3 groups, i.e.: negative control: group I; positive control: group II; crude extracts noni fruit: group III: combinations of crude extracts noni fruit and anti-TB drugs (K, AK, and OF). Each group was divided into three groups' doses of $30 \mathrm{mg} / \mathrm{ml}, 40 \mathrm{mg} / \mathrm{ml}$ and $50 \mathrm{mg} / \mathrm{ml}$. The Anti-tuberculosis activities of extracts noni fruit and $\mathrm{K}, \mathrm{AK}$, and OF against TB-MDR bacteria were tested by susceptibility test using proportion method in Lowenstein-Jensen (LJ) media.The anti-tubercular activity of noni fruits was determined by the minimum inhibitory concentration (MIC) of the bacterial growth at various doses $30 \mathrm{mg} / \mathrm{ml}, 40 \mathrm{mg} / \mathrm{ml}$, and $50 \mathrm{mg} / \mathrm{ml}$. The research design used post-test only contol group, and analyzed using analysis of variance and post hoct test. The extracted of Morinda c.Linn (noni) fruits have antitubercular activity to inhibiton of growth MDR-TB bacteria at various doses ( $p$ value=0,000). At a dose $30 \mathrm{mg} / \mathrm{m}$ lthe mean rate of the growth colonies of MDR TB-bacteria whit the mean rate 59,00 $\pm 27,81$, and at a dose $40 \mathrm{mg} / \mathrm{ml}$ was1,50 $\pm 2,81$. While at a dose of $50 \mathrm{mg} / \mathrm{ml}$ the bacterial colonies of MDR-TB did not grow in media. The combination of Morinda c.Linn (noni) fruit with anti-tuberculosis drugs, was the smallest groups to inhibit and eliminate MDR-TB bacteria at a dose $30 \mathrm{mg} / \mathrm{ml}(0,00 \pm 00.00)$. The experimental results confirmed the extracted of Morinda c.Linn (noni) fruits have antitubercular activity as well as anti-TB drugs, and the combination of the extracted of Morinda c.Linn (noni) fruits and anti-TB drugs was the best groups to inhibiton of growth MDR-TB bacteria.

Keywords: TB-MDR Bacteria, Morinda c. Linn (Noni), Anti-TB drugs, Anti-tubercular activity, MIC. 


\section{Introduction}

Tuberculosis (TB) is a contagious infectious disease that became the public health problems in the world [1]. Handling and controlling of TB is more complicated since the front line anti-tuberculosis drugs have gradually become ineffective for TB therapy [2]. The drug resistance could occurred due to the inadequate and unregularly drug utilization that cause gene mutation of the drug target such as Kat-G gene for isoniazid and rpo-B gene for rifampicin [3, 4]. Increased cases of Multidrug-resistant tuberculosis (MDR-TB) become obstacles in TB control. According WHO Global Tuberculosis Control, MDR-TB patients receiving treatment have a cure rate of less than $60 \%$ because TB treatment takes a long time, so that patients with treatment dropouts and bacteriological numbers remain positive causing resistant bacteria to develop into extensively drugresistant tuberculosis (XDR-TB), abbreviation for strains resistant to first and second line anti-tuberculosis drugs $[5,6]$. Due to the facts mentioned above and to TB latency, new anti-TB drugs and better therapeutic strategies against TB are urgently required. New drug candidates should shorten standard treatments and effective against MDR-TB bacteria. In spite of the efforts require supportive treatment from a natural product that has therapeutic effects for health such as noni (Morindacitrifolia Linn) [7, 8].

Noniis one of the medical plants that have been reported to have a therapeutic and nutritional value $[7,9,10]$. The leaves was largely used in traditional medicine and has been uses for arthritis, atherosclerosis, boils, burns, cancer, chronic fatigue syndrome, circulatory weakness, cold sores, congestion, constipation, diabetes, gastric ulcers, gingivitis, heart disease, hypertension and infections [11, 12]. Root of noni has been reported significant inhibitory effects on the proliferation of human lung and colon cancer cells $[13,14]$. The fruit juice of noni contains a polysaccharide-rich substance withantibacterial, antiviral, antifungal, antitumor, anthelmintic, analgesic, hypotensive, anti-inflammatory activity and enhance the immune effects $[15,16]$. Previous pharmaceutical study showed that, extract ofnonifruits effectively inhibit gram-positive and gram-negative bacteriasuch as Staphylococcus aureus,P.aureginosa strains Steptococcusmutans [17] Bacillus subtilis, Proteus morgaii, Pseudomonas, Escherichia coli $[7,18]$ moreover, the plants also utilizes to control the groups of pathogen bacteria,such Salmonella and Shigella [19].

Another anti-microbial in vitro assay was conducted on ethanol extract and hexane fractions noni leaves at $100 \mathrm{mg} / \mathrm{ml}$ reported to have an anti-tubercular activity in Mycobacterium tuberculosis cultures, with inhibition rates of $89 \%$ and $95 \%$ respectively [20]. [21] revealed that the ethanol extract of nonifruits showed that noni possessed in vitro anti-mycobacterial effect against Mycobacterium tuberculosisbacteriaat minimum 
inhibitory concentrations (MIC) $40 \mathrm{mg} / \mathrm{ml}$ [21].The anti-mycobacterialactivities of noni lead by the presence of active constituents such as secondary metabolites and lectins [22]. According phytochemical investigations of noni, the fruit contains of approximately 200 compounds from different parts of noni [23]. A number of major components in the noni plant was a scopoletin, flavonoids, octoaninic acid, potassium, vitamin C, terpenoids, alkaloids, antraquinones, which the ranged of the compounds antibacterial was $5.94 \mathrm{~g}$ to $36.52 \mathrm{~g} / 100 \mathrm{~g}$ of dry material [24-26]. The antimicrobial activity is generally attributed to various phytochemicals in noni extract that target bacterial cell membranes and cellular biochemical pathways $[23,27]$. The noni molecules react with lipids in bacterial cell membranes, resulting in increasing the cell-membrane permeability, disrupting the membranes, and breaking cell homeostasis, inactivate enzymes and denature proteins in bacteria $[15,19]$. Therefore the bacterial cell wall will be leakage of intracellular components, but also facilitate the movement of antimicrobial compounds into the cytoplasm, inducing cell death [28].

This study is to investigated the in-vitro anti-tubercular activity of extract noni fruit when is used as individual or combination with second-line anti-TB drugs against TBMDR strain bacteria at doses of $30 \mathrm{mg} / \mathrm{ml}, 40 \mathrm{mg} / \mathrm{ml}$, and $50 \mathrm{mg} / \mathrm{ml}$. Minimum inhibitory concentration (MIC) values were used in order to assess the synergistic activity of extract noni fruit.

\section{Material And Methods}

\subsection{Study design}

The research design used post-test only control group design [29].

\subsection{Samples}

The samples of this research are strain bacteria of Mycobacterium tuberculosis resistantto the first-line anti-tubercular drugs (rifampicin and isoniazid) based on drugsusceptibility sensitive test at the Health Laboratory of West Java Provincewas derived from sputum of patients with active TB as much as 54 strain. The sample was added aseptically to the Lowenstein Jonsen (LJ) medium and incubated at $37^{\circ} \mathrm{C}$ for 2 weeks with an optimum $\mathrm{pH}$ of 7.0 . 


\subsection{Reagents and antibiotics}

Reagent utilized in this study were, ethanol, etilasetat, $\mathrm{n}$ heksana, aquabidestilata, iron (II) klorida, natriumhidroksida 1 \%, (CV. GriyaSaranaMeditama, Bandung, Indonesia), dimethyl sulfoxide (DMSO), Ammonium sulphate, L. glumatic acid, sodium citrate (PT. Biogen Scientific Indonesia),Lowenstein Jensen (LJ Merck no. 105400), and glyserol (Merck cat. no. 104094). The antibioticskanamycins (K), amikacin (AK), danofloxacin (OF) were purchased from Sigma-Aldrich.

\subsection{Plantmaterial and Extraction}

The plant material of the present study is fresh mature of noni fruit that was collected during the rainy season in Cibeber, South Cimahi(2.8 Km from Cimahi city), West Java province, Indonesia. The plant voucher specimens of noni fruit (EN-no. 241571) were identified and authenticated at the Biomedical Sciences Laboratory of the Schoolof Health Sciences JenderalAchmadYaniCimahi.The fresh mature noni fruit was cleaned and sliced into small pieces, shade-dried at $50^{\circ} \mathrm{C}$ and ground to powder. The powdered noni fruit material (500 gr) was macerated with $500 \mathrm{ml}$ ethanol (96\%) in the increasing order of polarity from non-polar to high polar at $50^{\circ} \mathrm{C}$ for 2 hours. The extract was filtered through whatman No.1 filter paper, evaporated to dryness on a water bath until the solvent evaporated completely and yield of the crude extract.

\subsection{Experiment protocol}

The experiment were in-vitro experiment which divided into 3 groups, i.e.: negative control: group I; positive control: group II; crude extracts noni fruit: group III: combinations of crude extracts noni fruit and anti-TB drugs (K, AK, and OF). Each group was divided into three groups' doses of $30 \mathrm{mg} / \mathrm{ml}, 40 \mathrm{mg} / \mathrm{ml}$ and $50 \mathrm{mg} / \mathrm{ml}$. The Anti-tuberculosis activities of extracts noni fruit and $\mathrm{K}, \mathrm{AK}$, and OF against TB-MDR bacteria were tested by susceptibility test using proportion method in Lowenstein-Jensen (LJ) media. The crude extract of noni fruit was dissolved in $1 \mathrm{ml}$ of $20 \%$ DMSO (dimethysulfoxide), and anti-TB drugs was prepared in deionized water. The inoculum was adjusted $100 \mathrm{ml}$ dilution $10^{3}$ of TB-MDR bacteria by comparison with Mc. Farland standard to $10^{8} \mathrm{CFU} / \mathrm{ml}$ and spotted onto LJ media. All assays were run in duplicate, and kanamycin (30 mg/ml), amikacin $(40 \mathrm{mg} / \mathrm{ml})$ and ofloxacin $(2 \mathrm{mg} / \mathrm{ml})$ were utilized as positive controls. Cultivation was done at $37^{\circ} \mathrm{C}$ for 8 weeks. 


\subsection{Anti-tuberculosisactivity}

The anti-tuberculosis activity of extractnoni fruit and anti-TB drugs ( $K, A K$, or OF) were measure based onminimum inhibitor concentration (MIC) values expressed as the lowest concentration inhibition growth of colonies TB-MDR bacteria, while the determination of minimum bactericidal concentration (MBC) was indicated by clear zones around the medium using susceptibility test $[28,30]$.

\subsection{Statistical analysis}

All data were analysis using univariate analysis of variance, and the differences means \pm standard deviation between each group were evaluated by least significant difference (LSD) and Duncan's. Statistical analysis in this study using confidence interval 95\% $(p \leq 0.05)$. The experimental protocol of the current study has been approved by the Commission of Health Research Ethics Faculty of Medical, Diponegoro University and General Hospital dr. Kariadi Semarang with the issuance of Ethical Clearance letter.

\section{Result}

The qualitative observation from the crude extract of noni fruit and the combination of extract noni fruits with anti-TB drugs showed a significant activity of anti-tuberculosis against MDR-TB bacteria $(p<0.05)$. The anti-tuberculosis of crude extract noni fruit have different mean number of growth colonies TB-MDR bacteria at various doses $30 \mathrm{mg} / \mathrm{ml}$, $40 \mathrm{mg} / \mathrm{ml}$, and $50 \mathrm{mg} / \mathrm{ml}$ (Fig. 1).

The mean rate growth of colonies TB-MDR bacteria on the crude extract noni fruit at $30 \mathrm{mg} / \mathrm{ml}$ dose showed smaller mean compared to negative control (174.67+ 44.58) but greater than the positive control $(49.83 \pm 77.57)$. At the $40 \mathrm{mg} / \mathrm{ml}$ dose the growth colonies of TB-MDR bacteria had inhibited the growth colonies of TB-MDR bacteria better than the positive controls, and a dose of $50 \mathrm{mg} / \mathrm{ml}$ the bacterial colonies of TBMDR did not growth in LJ media (Table 1). According to that data, it can be shown that extract noni fruit can inhibit the growth of TB-MDR bacteria at doses $30 \mathrm{mg} / \mathrm{ml}$ and as bactericidal at $50 \mathrm{mg} / \mathrm{ml}$.

$\mathrm{CN}=$ control negative, $\mathrm{CP}=$ control positif, $\mathrm{EN}=$ extract noni fruit, $\mathrm{CEA}=$ combination of extract noni fruit and anti-TB drugs. Inhibitory zones in $\mathrm{mm}$, represented as mean \pm SD values $(n=72), 0=$ no zone. The values followed by different superscript differ significantly at $\mathrm{p}<0.05$ 
The combinations of extract noni fruit with anti-TB drugs ( $K, A K$, or OF)showed that at a dose of $30 \mathrm{mg} / \mathrm{ml}$, TB-MDR bacteria colonies didn't growth on the LJ media.The combination extract noni fruit and second-line anti-TB drugs was the best inhibitor compared with the single treatment of extract noni fruit, positive control, and negative control $(p<0.05)$. The combination of extract noni fruit and second-line anti-TB drugs showed synergistic activity against TB-MDR bacteria (Table 2).

$\mathrm{CN}=$ control negative, $\mathrm{CP}=$ control positif, $\mathrm{EN}=$ extract noni fruit, $\mathrm{CEA}=$ combination of extract noni fruit and anti-TB drugs Inhibitory zones in $\mathrm{mm}$, represented as mean \pm SD values $(n=72)$. The values followed by different superscript differ significantly at $p<0.05$. the mark indicate significant differences compared with the crude extract (LSD post hoc test; ${ }^{*}=\mathbf{p}<0.05 ;{ }^{* *}=\mathrm{p}<0.01$ )

The inhibitor of single noni fruit showed that extract noni is the best inhibiting the growth of Mycobacterium tuberculosis resistant of $\geq 80 \%$ compared to a negative control and $24 \%$ when compared with the positive control (table 3 ).

\section{Discussion}

The anti-TBdrugs were formulations or as fixed-doses combination were the major rule in killing of MTB or TB-MDR bacteria [2]. Anti-TB drugs are strong bactericidal and bacteriostatic in inhibiting the growth of Mycobacterium bacteria. The target of Treatments of infectious diseases such as MDR TB facing serious problem worldwide, as microorganisms become resistant to multiple antimicrobial agents, which lead to increase TB cases incidence [31]. Based on that phenomena, development of new therapeutic from local plants traditionally such as noni fruit that may can efforts the affectivityof anti-TB for the treatment of TB [26].

Noni fruit is one of themedical plant as well as some other compounds in noni root and leaves, are all proved as antibacterial agents $[24,25]$. The results of the present study showed the crude extract noni fruit have a significant differenceof the growth of TB-MDR bacteria. The antibacterial activity of noni against certain infectious bacterial strains was reported [7, 11, 27, 32, 33]. [17] reported that noni fruit extract can inhibit zone diameter Streptococcus mutant growth in $330.66 \mathrm{~mm}^{2}$ [17]. Another study of affectivity noni against $E$. coli, Salmonella typhii, and Bacillus cereus, C. albicans, and S. aureus reported by Usha (2010). Anti-tubercular effects of Saludes research, reported that leaves form noni has been found killed 89 percent of the bacteria M. tuberculosis [20], and noni fruits killed M.tuberculosis bacteria at $40 \mathrm{mg} / \mathrm{ml}$ [21]. 
The anti-tubercularactivity extract noni might be influenced by the presence of secondary metabolites as phenolic compounds [34]. Phenolic compounds contained in the noni fruit ranged from 5.94 to $36.52 \mathrm{~g} / 100 \mathrm{~g}$ of dry material [26, 35]. Phytochemicals in noni molecules are associated with the defense mechanisms of plants by their repellent or attractive properties, protection against biotic and abiotic stresses, and maintenance of structural integrity of plants $[30,36]$. In addition the molecules of noni react with lipids in bacterial cell membranes, resulting in increasing the cell-membrane permeability, disrupting the membranes, and breaking cell homeostasis, inactivate enzymes and denature proteins in bacteria $[18,19]$. Therefore the bacterial cell wall will be leakage of intracellular components. It further disrupts the transport of important organic ions into the cells resulting in inhibition of growth even in cell lysis [36-38].

The decrease of MIC value showed that the combination of extract noni fruit and antiTB drugs found to have synergistic activity that can inhibit the growth of TB-MDR at low doses. The combination of extract noni fruit and anti-TB drugs possible, makesynergism and complementary effects of active substances that can enhance the activity were more effective than the individual agents $[39,40]$.The combinations will be improved bacterial potential of extract noni fruit and anti-TB drugs as combined antymycobacterial cell wall [41]. Based on several studies the extract noni effectively have an antibacteria activity that can inhibit and eliminate the bacteria.Another study showed that noni fruit was found relatively non-toxic $[10,35]$.

\section{Conclusion}

The present study brought out the fact that extract have anti-tuberculosis activity againstTB-MDR bacteria. The combination of extractsnoni fruitand anti-TB drugs showed significant most active compound compared the individual drugs.Based on the results obtained,nonifruits can be a potential source of drugsas an adjuvant therapy for anti-tuberculosis drugs. However, further studies required tocarry out in in vivo, ex vivo and clinical trialinvestigations of nonifor alternative treatment of tuberculosis problems.

\section{Conflict of interest}

This study is important because lung Tuberculosis remains a global health problem, especially MDR TB disease increased even XDR TB due to drug resistance. Treatment strategy is required for supportive treatment of natural ingredients that Morindacitrifolia (noni), which may contribute to the treatment of TB. Noni is a plant that is easy to obtain 


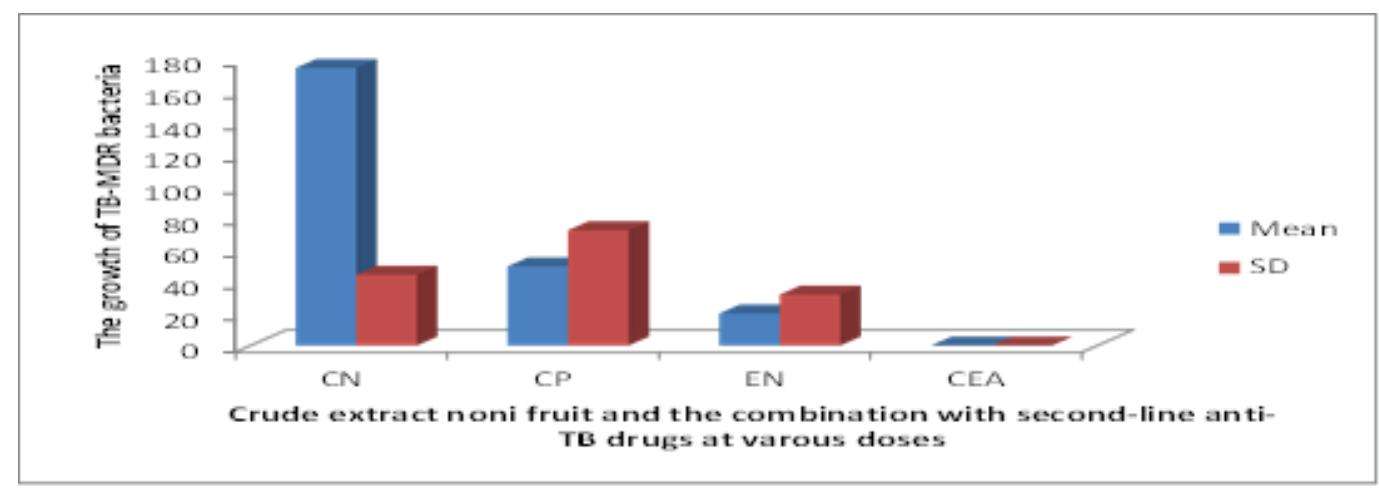

Figure 1

TABLE 1: Antimicrobial activity of crude extracts noni fruit and the combination with second-line anti-TB drugs

Sample
CN
CP
K
AK
OF
EN
CEA

$30 \mathrm{mg} / \mathrm{ml}$
$174.67 \pm 44.58$
$0 \pm 0$
$0 \pm 0$
$49.83 \pm 72.57$
$59.00 \pm 27.81$
$0 \pm 0$

\begin{tabular}{|c|c|}
\hline Doses \\
$\mathbf{4 0} \mathbf{~ m g} / \mathrm{ml}$ \\
$174.67 \pm 44.58$ \\
\\
$0 \pm 0$ \\
$0 \pm 0$ \\
$49.83 \pm 72.57$ \\
$1.50 \pm 2.81$ \\
$0 \pm 0$ \\
\hline
\end{tabular}

$\mathbf{5 0} \mathbf{~ m g} / \mathbf{m l}$
$174.67 \pm 44.58$
$0 \pm 0$
$0 \pm 0$
$49.83 \pm 72.57$
$0 \pm 0$
$0 \pm 0$

TABLE 2: Combination testing of extract noni fruit and anti-TB drugs againstTB-MDR bacteria

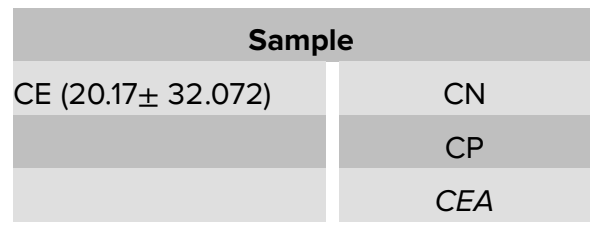

\begin{tabular}{|l|}
\hline Mean \\
\hline 174.67 \\
\hline 49.83 \\
\hline 0.00 \\
\hline
\end{tabular}

\begin{tabular}{c|} 
SD \\
\pm 44.5751 \\
\pm 72.567 \\
0.00
\end{tabular}

p value
$0.000^{*}$

TABLE 3: The effectiveness noni fruit compared the control of Mycobacterium tuberculosis

Compounds
control +
Extract Noni

\begin{tabular}{|c|c|}
\hline \multicolumn{2}{|c|}{ \% Effectivety } \\
\hline control + & \\
& control - \\
\hline 24 & 87 \\
\hline
\end{tabular}

and have side effects were relatively minor and easily accessible by the public. This study aims to explain the influence the anti-tubercular activity of extractand compounds noni fruit to inhibition the growth of MDR TB bacteria. This manuscript has not been published and is not under consideration for publication to any other journal or any other type of publication (including web hosting) either by me or any of my co-authors. 


\section{Acknowledgments}

We thanks to Prof. dr. Edi Dharmana, Sp.Par(K), M.sc, Ph.D; Prof dr.HardhonoSusanto, PAK(K); Dr. Muchlis AUS., SpPD-KPTI;Dr. dr Sri Andarini I., M.Kes, Dr. Dyan K. Nugrahaeni, SKM., MKM and to their contribute for this research.

\section{References}

[1] WHO. (2016). Global Tuberculosis Report. Switzerland.

[2] WHO. (2016). Multidrug-Resistant Tuberculosis Fact Sheet 2016, 2015-2016. Switzerland.

[3] Palomino, J. and Martin, A. (2014). Drug Resistance Mechanisms in Mycobacterium Tuberculosis. Antibiotics, vol. 3, issue 3, pp. 317-340.

[4] WHO. (2016). WHO Treatment Guidelines for Drug-Resistant Tuberculosis. Geneva: World Health Organisation.

[5] Region, S. A. (2015). Tuberculosis Control in South-East Asia Region.

[6] WHO. (2016). Tuberculosis Profile. Pan American Health.

[7] Singh, R. (2012). Morinda Citrifolia L. (Noni): A Review of the Scientific Validation for its Nutritional and Therapeutic Properties. Journal of Diabetes and Endocrinology, vol. 3, issue 6, pp. 77-91.

[8] Wang, M.-Y., et al. (2002). Literature Review and Recent Advances in Noni Research. Acta Pharmacol Sin, vol. 23, issue 12, pp. 1127-1141.

[9] Solomon, N. (1999). The Noni Phenomenon, Discover the Powerful Tropical Healer that Fights Cancer. Losers Hight Blood Preasure and Relives Chronic Plan. South Geneva Rood: Direct Source Publising.

[10] West, B. J., et al. (2006). A Safety Review of Noni Fruit Juice. Journal of Food Science, vol. 71, issue 8, pp. 100-106.

[11] Gupta, R. K. and Patel, A. K. (2013). Do The Health Claims Made for Morinda Citrifolia (Noni) Harmonize with Current Scientific Knowledge and Evaluation of its Biological Effects. Asian Pac J Cancer Prev, vol. 14, issue 8, pp. 4495-4499.

[12] Peter, P I. (2007). Clinical Research on Morinda Citrifolia L. Noni Research Cinical Journal, vol.1.

[13] Ali, M., Kenganora, M. and Manjula, S. N. (2016). Health Benefits of Morinda citrifolia (Noni): A Review. Pharmacognosy Journal, vol. 8, issue 4, pp. 321-334. 
[14] Srinivasahan, V. and Durairaj, B. (2015). In Vitro Cytotoxic and Apoptotic Activity of Polysaccharide Rich Morinda Citrofolia Fruit on Mcf-7 Cells. Asian Journal of Pharmaceutical and Clinical Research, vol. 8, issue 2, pp. 190-193.

[15] Haque, M. and Rao, U. S. M. (2013). Modulatory Effect of Mengkudu Fruit on the Activities of Key Enzymes of Glucose Synthesis and Utilization Pathways of Diabetic Induced Rats. Journal of Pharmacy Research, vol. 7, issue 1. DOI: 10.1016/j.jopr.2013.01.003

[16] Pai, A. R., et al. (2015). Green Synthesis and Characterizations of Silver Nanoparticles using Fresh Leaf Extract of Morinda Citrifolia and its Anti-Microbial Activity Studies. International Journal of Pharmacy and Pharmaceutical Sciences, vol. 7, issue 3. Page 459-461

[17] Malinggas, F., Pangemanan, D.H.C. and Mariati, N W. (2015). Uji Daya Hambat Ekstrak Buah Mengkudu (M. Citrifolia L.) Terhadap Pertumbuhan Streptococcus Mutans Secara In Vitro. Pharmacon Jurnal IImiah Farmasi - Unsrat, vol. 4, issue 4, pp. $22-26$.

[18] Gupta, R. K. and Patel, A. K. (2013). Do the Health Claims made for Morinda Citrifolia (Noni) Harmonize with Current Scientific Knowledge and Evaluation of its Biological Effects. Asian Pacific Journal of Cancer Prevention. 14(8):4495-4499. DOI: 10.7314/APJCP.2013.14.8.4495

[19] Yang, J., Afaisen, S. J. and Gadi, R. (2016). Antimicrobial Activity of Noni Fruit Essential Oil on Escherichia Coli O157:H7 and Salmonella Enteritidis 1, January issue, pp. 1-10.

[20] Saludes, J. P., et al. (2002). Antitubercular Constituents from the Hexane Fraction of Morinda citrifolia Linn. (Rubiaceae). Phytotherapy Research, vol. 16, issue 7, pp. 683-685.

[21] Mauliku, N. E., et al. (2017). Anti-Tubercular Activity of Extract and Coumponds of Noni (Morinda citrifolia Linn). International Journal of Pharmacy and Pharmaceutical Sciences, vol. 9, issue 12, pp. 105-109.

[22] Paiva, P. M. G., et al. (2010). Antimicrobial Activity of Secondary Metabolites and Lectins From Plants. Current Research, Tecnology and Education Topics in Applied Microbiology and Microbial Biotechnology, pp. 396-406.

[23] Markandeyan, D., et al. (2015). Virtual Screening of Phytochemicals of Morinda Citrifolia as Anti-Inflammatory and Anti-Alzheimer Agents using Molegro Virtual Docker on P38 $\alpha$ Mitogen-Activated Protein Kinase Enzyme. Asian Journal of Pharmaceutical and Clinical Research, vol. 8, issue 6, pp. 141-145.

[24] Deng, S., West, B. J. and Jensen, C. J. (2010). A Quantitative Comparison of Phytochemical Components in Global Noni Fruits and their Commercial Products. 
Food Chemistry, vol. 122, issue 1, pp. 267-270.

[25] Lv, L., et al. (2011). Chemical Components of the Roots of Noni (Morinda Citrifolia) and their Cytotoxic Effects. Fitoterapia, vol. 82, issue 4, pp. 704-708.

[26] Motshakeri, M. and Ghazali, H. M. (2015). Nutritional, Phytochemical and Commercial Quality of Noni Fruit: A Multi-Beneficial Gift from Nature. Trends in Food Science and Technology, vol. 45, issue 1, pp. 118-129.

[27] Sathishkumar, G., et al. (2012). Phyto-Synthesis of Silver Nanoscale Particles using Morinda Citrifolia L. and its Inhibitory Activity against Human Pathogens. Colloids and Surfaces B: Biointerfaces, vol. 95, March issue, pp. 235-240.

[28] Brooks, G. F. and Carroll, K. C. (2007). Mycobacteria. In M. Jawetz and Adelberg (Eds.), Medical Microbiology (24 ${ }^{\text {th }}$ ed.). USA: The McGraw-Hill Companies, Inc., pp. 320-331.

[29] Sastroasmoro, S. I. (2014). Dasar-Dasar Metodologi Penelitian Klinis. Jakarta: Sagung Seto.

[30] Ríos, J. L. and Recio, M. C. (2005). Medicinal Plants and Antimicrobial Activity. Journal of Ethnopharmacology.

[31] WHO. (2014). Companion Handbook. Geneva: World Health Organization.

[32] Antara, N. S. and Prabanca, V. G. (2014). Aktivitas Antimikroba Ekstrak Bubuk Buah Mengkudu (Morinda citrifolia L.) Terhadap Pertumbuhan Bakteri Patogen, vol. 1, issue 1, pp. 1-9.

[33] West, Brett J., et al. (2012). Antimicrobial Activity of an Iridoid Rich Extract from Morinda citrifolia Fruit. Current Research Journal of Biological Science, vol. 4, issue 1, pp. 52-54.

[34] Dewi, N. (2012). Khasiat dan Cara Olah Mengkudu Untuk Mengobati Berbagai Penyakit. Yogyakarta: Pustaka Baru Press.

[35] Potterat, O. and Hamburger, M. (2007). Morinda Citrifolia (Noni) fruit - Phytochemistry, Pharmacology, Safety. Planta Medica, vol. 73, issue 3, pp. 191-199.

[36] George, S. A., et al. (2017). Comprehensive in Vitro Evaluation of Pharmacological Activities of Selected Plant Extracts and Gas Chromatograph Y-Mass Spectrometry Profiling of Flacourtia Jangomas Flower Extract, Asian Journal of Pharmaceutical and Clinical Research 10(5):237 vol.10, issue 5. DOI: 10.22159/ajpcr.2017.v10i5.17419

[37] Al-Otaibi, J. S. and Gogary, T. M. (2017). Synthesis of Novel Anthraquinones: Molecular Structure, Molecular Chemical Reactivity Descriptors and Interactions with DNA as Antibiotic and Anti-Cancer Drugs. Journal of Molecular Structure, vol. 1130, pp. 799809. 
[38] Arya, V. (2011). A Review on Anti-Tubercular Plants. International Journal of PharmTech Research, vol. 3, issue 2, pp. 872-880.

[39] Martins, D. and Nunez, C. V. (2015). Secondary Metabolites from Rubiaceae Species. Molecules, vol. 20, issue 7, pp. 13422-13495.

[40] Pandy, V., et al. (2014). Effect of Noni (Morinda citrifolia Linn.) Fruit and Its Bioactive Principles Scopoletin and Rutin on Rat Vas Deferens Contractility: An Ex Vivo Study. The Scientific World Journal, pp. 1-11.

[41] Pitaloka, D. A. E. and Sukandar, E. Y. (2017). in Vitro Study of Ursolic Acid Combination First-Line Antituberculosis Drugs Against Drug-Sensitive and Drug-Resistant Strains of Mycobacterium Tuberculosis. Asian Journal of Pharmaceutical and Clinical Research, vol. 10, issue 4, pp. 8-10. 